\title{
Joint visit of Canadian and Soviet scientists to the northeastern Soviet Union ${ }^{1}$
}

In 1989, as part of a Canada-USSR exchange agreement, Soviet and Canadian scientists traversed Chukotka (the Chukotsky Peninsula) from the Arctic coast south of Wrangel Island to $\mathrm{Ma}$ gadan on the Sea of Okhotsk. The first part of this trip was along the Chukotkan (Chukotsky) coast, where an intrusive body and a potential basement complex, both of Paleozoic and (or) Proterozoic age, were examined and sampled for radiometric analysis. The potential basement complex is migmatitic and has structural trends that are different from those in the younger strata. In addition, all the pre-Cretaceous strata in this region were extensively and penetratively deformed during more than one phase of deformation.

The second part of the trip was in the center of Chukotka, in the area of the hypothesized suture zone (South Anyui) between the Arctic AlaskaChukotka (ancestral) plate and the terranes of southern Chukotka, Here, hypothesized ophiolite bodies were found to be layered pyroxenites and gabbros that are very similar to the Kanuti ophiolite of Alaska. In addition, we found that Permian to Jurassic deep-water strata include abundant volumes of volcaniclastic and volcanic rocks. The major deformation of these strata began in the Middle Jurassic and was completed by the late Early Cretaceous.

The third and final part of this visit was a traverse across the Okhotsk-Chukotsk volcanic belt in southern Chukotka. This is a belt of relatively undeformed epicontinental volcanic rocks that overlaps all terranes found in Chukotka and thus fixes relative movement among these terranes as prior to the late Early Cretaceous.

\footnotetext{
${ }^{1}$ Geological Survey of Canada contribution number 48190, a result of the Canada/USSR Scientific and Technological Exchange Agreement
}

\section{Introduction}

Theme 1 of the 1984 Canada and USSR Arctic Scientific and Technological Exchange Agreement, Geological Science and Arctic Oil, is the comparison of the geologic evolution of arctic regions and the hydrocarbon resources of both countries. One of this theme's projects is the comparison of key geologic provinces around the Amerasian basin. Integral to this comparison is the study of the Arctic Alaska-Chukotka (ancestral) plate (AACP; northern Alaska, USA, northern Chukotka, USSR, and their arctic continental shelves; the Arctic Alaska-Chukotka terrane of Churkin, 1982). The hypothesis on the opening of the Canada Basin proposes that the AACP separated from the Canadian Arctic Islands sometime during the Mesozoic and moved to its present location through strike-slip motion or rotation (Embry and Dixon, 1989). Two of the objectives of this comparison project will be to provide a better mutual understanding of the geology of the region and to better constrain the hypotheses concerning formation of the Canada Basin (Cecile and others, 1988).

Fieldwork for this project began in 1985 when two Soviet geologists visited Melville Island in the Canadian Arctic Islands, and this was followed in 1986 with a visit by two Canadian geologists to Wrangel Island off the Chukotkan coast of the USSR (Cecile and Harrison, 1986). In 1988 three Soviet geologists participated in fieldwork in the northwestern Canadian Cordillera near the Beaufort Sea coast, and in 1989 the authors participated in 4 weeks of fieldwork in the northeastern Soviet Union. This is a brief report highlighting the results of this latest fieldwork.

The fieldwork in the northeastern Soviet Union (fig. 1) had three primary objectives. The first was to examine the Proterozoic, Devonian, and Carboniferous strata exposed on the Arctic coast immediately south of Wrangel Island in order to expand our understanding of older geology examined previously in detail on Wrangel Island (Kos'ko and others, 1990; Cecile and Harrison, 1986, 1987a, b), as well as to look for more Late Proterozoic metasedimentary and igneous rocks like those exposed in the middle of Wrangel Island (Kos ko and others, 1990). The second objective was to examine rocks in the area of the South Anyui and adjoining Oloi zones, including their ultramafic rocks. The South Anyui-Oloi area is hypothesized to be the suture between the AACP and other terranes that amalgamated with Chukotka on its southern (Pacific) side (Seslavinsky, 1979). The third objective was to examine the Okhotsk-Chukotsk volcanic belt and its relationship to older strata. This volcanic belt (Shilo and others, 1984; Kosygin and Parfenov, 1981; Belyi, 1973, 1977) is hypothesized to be a continuous epicontinental chain that, by late Early Cretaceous time, overlapped virtually all the suspect terranes of the far northeastern Soviet Union, as well as Eurasia (Rowley and Lottes, 1988). This overlap means that the assembly of the AACP with smaller blocks on the Pacific side (like those shown in fig. 1 that are cored by Archean and Proterozoic rocks), together with the Eurasian (ancestral) plate, would have had to have been completed before the late Early Cretaceous. 


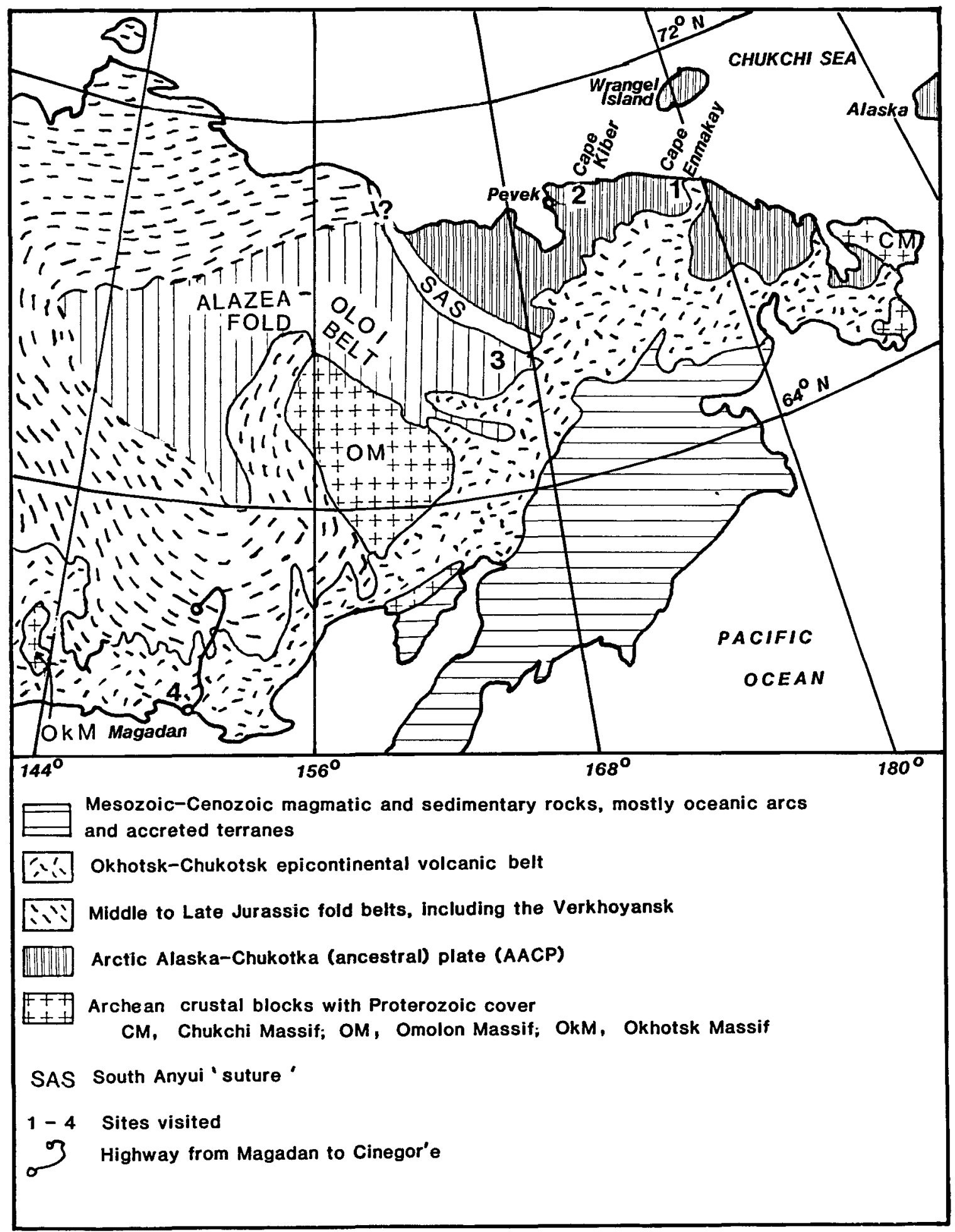

Figure 1.-Major geologic divisions in the far northeastern Soviet Union (data modified from Kosygin and Parfenov, 1981, and incorporated from map of Rozenbloom and others, 1987). The fact that the volcanic rocks are epicontinental means that the Okhotsk-Chukotsk belt is an overlap assemblage and that all the terranes overlapped by it must have amalgamated before the late Early Cretaceous (middle Albian). Rocks in all zones north of the Okhotsk-Chukotsk belt, excluding massifs, underwent major deformation in the Middle to Late Jurassic, which continued locally into the Early Cretaceous. 


\section{Cape Enmakay, Arctic coast}

\begin{abstract}
Our first field camp was in the area of Cape Enmakay (southsouthwest of Wrangel Island, $300 \mathrm{~km}$ east of the city of Pevek, District of Chukotka, Magadan Region) on the Arctic coast (fig. 1), where we were hosted by district geologist, A.A. Yegorov. Here we examined a long coastal section of Devonian clastic strata described by Rogozov and Vasil eva (1968), as well as lower Carboniferous sandstone and conglomerate that unconformably overlie the Devonian strata. In addition, we examined a large granitic complex, which contains well-developed mylonite zones, plus Upper Triassic rocks and, at many locations, Upper Cretaceous volcanic rocks, part of a northern extension of the Okhotsk-Chukotsk volcanic belt.
\end{abstract}

Some highlights of our findings from this area are as follows. (1) The Devonian outcrops along the coast are complicated structurally by fold and fault repetitions. Fossils are rare. Existing published sections of the stratigraphy of Rogozov and Vasil'eva (1968), which imply a simple stratigraphic succession, are, in fact, an interpretation of a structurally complex coastal exposure. Rogozov and Vasil'eva established some basic stratigraphic subdivisions. but the structural and stratigraphic relationships among units are uncertain. (2) The composition and depositional framework of Devonian strata, the unconformity below the Carboniferous contact, and the nature of the lower Carboniferous conglomerate at Cape Enmakay are all similar to those observed on Wrangel Island. The Devonian strata generally represent deposition in fluvial and coastal marine settings and are mostly quartzites along with siltstones, mudstones, and minor units of fossiliferous carbonate rocks. The unconformity below the Carboniferous strata consists of lower Carboniferous conglomerates that are composed of locally derived sedimentary rock clasts. These clasts are present in a variety of shapes and sizes and rest with low-angle unconformity on the older Devonian strata. (3) A large granitic body exposed along the Obryvistyi River near Cape Enmagir (west side of location 1, fig. 1) has migmatite phases and was emplaced northwestward onto metasedimentary gneisses along a mylonitic thrust fault zone. It is itself cut by mylonites. This northwest-directed thrusting is not expressed in Devonian and younger strata. The body is also the only garnetiferous granite and the only one with gneissic foliation that we observed throughout our fieldwork. Potassium-argon (K-Ar) ages of 100-60 Ma were obtained from a separate small body of granodiorite that was found within the southeastern end of this pluton. In many areas here, an apparent intrusive relationship exists between the Lower Cretaceous strata and the larger granitic body (M.E. Gorodinsky, oral communication, 1989). On local unpublished maps, the pluton is shown to be cut by several linear mylonite zones that trend west-northwest, and it includes migmatized bodies of Lower to Middle Devonian(?) clastic rocks and lower Carboniferous strata. All this information suggests that this is an intrusive complex that may include within it older Paleozoic or Proterozoic basement. Samples were collected from this granite to be used for additional radiometric analysis. (4) Structural fabrics in coastal outcrop sections indicate that the structural history of the area consists of several superimposed deformations that could be bracketed according to the ages of strata affected. As noted above, the northwest-directed thrusting observed in the large granitic complex apparently is not expressed in the Devonian and younger strata. However, west- or southwest-overturned nappes, followed by eastward-overturned folds and related thrust faults, affected the Devonian to Upper Triassic sequence. Upper Cretaceous volcanic rocks, which unconformably overlie the Triassic sediments, postdate the deformation. (5) Because the northeastern Soviet Union was mostly free of ice during the last glaciation and because of its current climatic conditions, many exposures in this region are dominantly felsenmeer. Available geological maps are at scales no larger than 1:500,000 and are based mainly on the distribution of scattered outcrops and large areas of felsenmeer. Because of this data base and map scale, it is difficult or impossible to show contact relationships that reflect the structural complexit that is apparent from detailed study of outcrops. Therefore, geologists having no field experience in the area could infer from the map that the structure of the area is much simpler than it actually is.

\section{Cape Kiber, Arctic coast}

Our second field camp was a few kilometers southeast of Cape Kiber $(100 \mathrm{~km}$ east of the city of Pevek, District of Chukotka. Magadan Region; fig. 1), and we were hosted by regional geologis: S.F. Begunov from the Pevek Expedition. Here we examined it Paleozoic(?) (Kiber) granite and associated Paleozoic strata for comparison with Wrangel Island. Existing unpublished measured stratigraphic sections by N.M. Vasil 'eva and Yu.G. Rogozov plus unpublished maps provided by S.F. Begunov indicate that the area consists of a simple anticlinal structure having a large granitic core, the soutli half of this anticline being exposed in the Cape Kiber area and the north half under the sea. The stratigraphic sections, measured along the south limb of this structure, were interpreted as a simple southwest-facing homoclinal sequence of Devonian(?) clastic strat: that was intruded by granite in the north and was overlain by Carboniferous to Triassic strata in the south.

S.F. Begunov has observed in local mapping that the structure is much more complex than is shown in previous work. Detailed analysis of the structural fabric reveals that the exposures along the seit coast on the south limb of the "anticline" do not represent a simple stratigraphic sequence. Instead, these exposures are cliffs cut paralle to the strike direction of isoclinal folds overturned to the northeast.

In the north, the Devonian(?) argillite, siltstone, and sandstone succession (fig. 2) is deformed complexly by several tight isoclinal folds and thrust faults. These rocks are intruded by the Kiber granite. and for a few tens of meters from the granite, they have undergont contact metamorphism. South of this, the sedimentary succession appear to be disposed in two large overturned synclines that ar: juxtaposed on a fault or shear zone. The upper (southern) syncline has a core of an older (mapped as Carboniferous(?)) argillite, siltstone, and sandstone sequence; the lower (northern) syncline has a core of fossiliferous Carboniferous limestone and associated sandstones and conglomerates. In the sea cliffs, the fault coincides with the structural top of the overturned limestone. The contact is not exposed between the rocks of the northern Carboniferous limestonebearing syncline and the sequence of complexly deformed Devonian(?) clastic strata to the north. Southwest of the two overturned synclines are well-documented occurrences of Triassic clastic rocks. but their contact with the northern coastal strata is not defined clearly.

The clastic sequence in the upper (southern) syncline was assigned a Carboniferous(?) age because it was assumed to be in normal stratigraphic position. In fact, these strata strongly resemble clastic rocks that are found structurally below both synclines and are intruded by Kiber granite. If we consider the nature of deformation in the area, the clastic strata in the upper syncline may be simply a repeat of the structurally lowest Devonian(?) clastic rocks.

Both granitic and sedimentary clasts are found in the Carboniferous conglomerates of the lower (northern) syncline. The granitic clasts resemble the granite exposed on Cape Kiber, and the sedimentary clasts appear to be derived exclusively from strata identical to the Devonian(?) succession that is intruded by the granite.

The Kiber granite also is complicated. The possibility of more than one granitic intrusion exists. Although deformed granitic dikes 

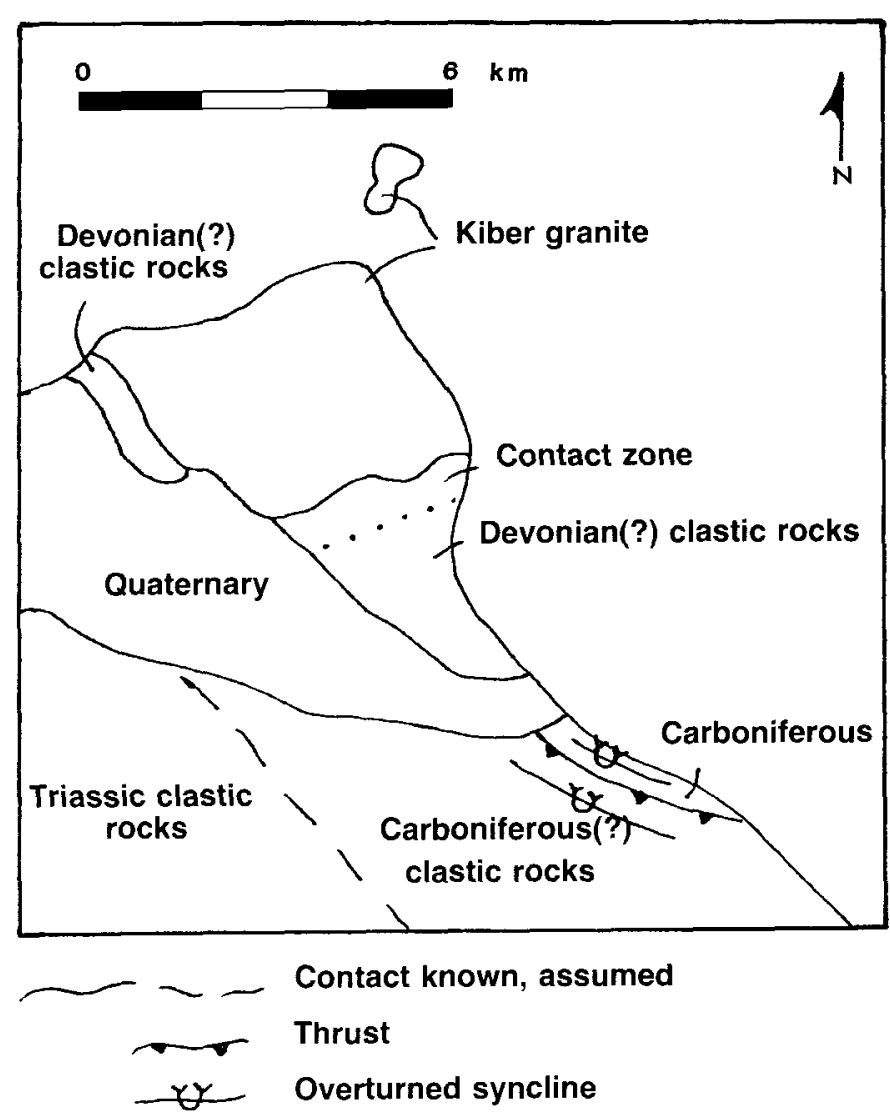

Figure 2. - The main geologic and structural features of the Cape Kiber area, USSR. Dotted line shows extent of contact zone.

are found near the intrusion, as well as granitic clasts in the Carboniferous conglomerate, no major deformation appears on some of the dike rocks in the contact area of the intrusion itself. In addition, the age of the granite has not been established clearly. Clasts in the Carboniferous conglomerates indicate a middle Paleozoic or premiddlc Paleozoic age. The age of the intruded clastic rocks has been assigned to the Devonian(?), but the rocks may, in fact, be much older. Because of this, several samples were collected from this pluton for radiometric analysis.

\section{Bol'shoi Anyui Camp, central part of Chukotka}

Our third field camp $(150 \mathrm{~km}$ south of Bilibina, District of Chukotka, Magadan Region) was on a tributary to the Bol'shoi Anyui River, the Burgakhchan River (fig. 1). Here we were hosted by C.V. Paraketsov and his wife, G.I. Paraketsov, both of whom have vast experience with Mesozoic rocks across the far northeastern USSR. From this camp, we examined rocks in the Oloi zone (Shilo and others, 1973) and, briefly, rocks in the South Anyui zone Seslavinsky, 1979). The main purpose of this camp was to gain familiarity with the regional geology of the hypothesized "suture" zone between the AACP and the other terranes of the far northeastern Soviet Union, the emphasis being put on the age of "suturing." The strata we examined ranged in age from the Permian through the Cretaceous.

Some of the highlights of our examination of the Oloi and South Anyui zones were as follows. (1) The abundance of volcaniclastic and volcanic rocks (intermediate to acidic tuffs, ignimbrites and flows, and minor basalt) in Permian, Triassic, and Jurassic deepwater strata was followed by a change in the Early Cretaceous (Aptian to Albian) to shallow-water clastic rocks containing coal. The geology here has been interpreted by C.V. Paraketsov (oral communication, 1989) by using classic methods of assigning stratigraphic units to eugeosynclinal (late Paleozoic, Triassic, and Jurassic, ending in the Bathonian), early orogenic (Oxfordian to Volgian), late orogenic (middle to late Volgian to Early Cretaceous), and postgeosynclinal depositional stages (beginning in late Early Cretaceous (Albian)). The significance of this analysis is that it allows interpretation of the tectonic history of the area using the sedimentary record, and from this, we infer that collision or "suturing" in this area would have been initiated during Middle Jurassic (Bathonian) time and would have been completed by or during late Early Cretaceous (Albian) time. (2) Ultramafic complexes in the Oloi and South Anyui zones consist of layered intrusive complexes of probable Triassic or older age that are now everywhere in tectonic contact with surrounding strata. Western geologists and some Soviet geologists believe these rocks to be obducted pieces of ocean floor that have all its characteristic features, including sheeted dikes and spilites. However, at the four localities we visited, we observed only layered ultramafic bodies and no other parts typical of the "ophiolite sequence." The outcrops that we examined are dominantly pyroxenites and some gabbros, which frequently show crude, and locally welldeveloped, layering that, in places, has steep to gentle dips. In many places, the ultramafic rocks are cut by zones of serpentinite. Preliminary work on the mineralogy indicates that the ultramafic bodies in the Oloi zone are dominated by orthopyroxene (bronzite) and olivine plus serpentine minerals, whereas the ultramafic rocks of South Anyui contain both orthopyroxenes and clinopyroxenes plus olivine and serpentine minerals. In two localities, we also saw layered gabbros, one of which we observed in the Anyui zone to be in transitional contact with a larger body of pyroxenite.

We examined in detail a well-exposed contact between ultramafic rocks and Upper Jurassic volcanic rocks in the Oloi zone. There, at the contact, we observed fine grain sizes within the ultramafic body, which became medium-sized grains away from the contact. A few hundred meters within the ultramafic body, we observed a marked change from medium to coarse grain sizes. The contact itself was marked by zones of sheared serpentinite and mylonite. A second contact area also was examined, but no outcrop remains. However, in the contact zone, we found felsenmeer consisting of serpentinite and mylonite along with pyroxenite.

The ultramafic bodies have been dated indirectly. Upper Triassic sandstone found along the Bol'shoi Anyui River contains spinel and clasts that are typical of the ultramafic rocks exposed in the region (C.V. Paraketsov, oral communication, 1989). This provides a minimum Late Triassic age for emplacement of at least some of these ultramafic rocks.

These ultramafic rocks are compositionally and structurally, as well as in terms of their relative tectonic position, very similar to the Kanuti ophiolite that is found on the flanks of the Yukon-Koyukuk basin in Alaska. The Kanuti ophiolite is of probable Jurassic age and is a partial ophilite consisting of harzburgite (olivine and orthopyroxene), dunite, and layered ultramafic and gabbroic rocks (Loney and Himmelberg, 1989). 


\section{Magadan to Cinegor'e traverse} This part of the trip was led by M.E. Gorodinsky, Chief Geologist
with the Proizvodstvennoe Geologicheskoe Ob edinenie (PGO)
Sevostgeologia in the port city of Magadan. The trip consisted of a
jeep traverse along about $500 \mathrm{~km}$ of highway north of Magadan (fig.
1) on the Sea of Okhotsk to the headwaters of the Kolyma River at
the city of Cinegor'e, Magadan Region, USSR. The purpose of this
phase of fieldwork was to examine a variety of Triassic and Jurassic
outcrops of the southeastern Verkhoyansk fold belt, as well as the
overlying rocks of the Cretaceous Okhotsk-Chukotsk volcanic belt.
in order to assess the constraints that this volcanic belt has on the age
of an assembly of terranes in the far northeastern Soviet Union. The
volcanic rocks we observed are a mixture of mildly deformed basalts,
andesites, dacites, rhyolites, tuffs, and ignimbrites, which were de-
posited on penetratively deformed upper Paleozoic and Mesozoic
sedimentary strata of the southeastern Verkhoyansk fold belt. The
Okhotsk-Chukotsk belt has been dated by flora and fauna as forming
basically in middle Albian time (Belyi, 1977 ), although in a few
sections, collections give Aptian to Albian ranges, and in one sec-
tion, a questionable Hauterivian age has been suggested (Belyi,
1977 ). Belyi dates the upper part of the Okhotsk-Chukotsk belt as
Cenomanian and reports that from 1970 to 1975 some 250 analyses
were performed on various collections from the Okhotsk-Chukotsk
belt in order to determine K-Ar radiometric ages. Of these analyses,
20 percent gave a range of 110 to 90 Ma and the remainder, 90 to 60 Ma.

The Okhotsk-Chukotsk belt is clearly epicontinental, and all the continental blocks and folded sedimentary terranes overlapped by this linear volcanic belt had to have been assembled together prior to the late Early Cretaceous, as noted recently by Rowley and Lottes (1988). This is a particularly important point because, through analysis of sedimentary successions and major unconformities around the Amerasian basin, most Western geoscientists now feel that the Canada Basin began to form only in late Early or early Late Cretaceous time (Embry and Dixon. 1989). If all these observations are correct, then all the continental plates of the northeastern Soviet Union-and thus northern Alaska (AACP) - cannot be involved in the formation of the Canada Basin. Either that or else the terranes of the far northeastern Soviet Union must have been moved as a unit, together with the Eurasian (ancestral) continental plate, in order to open the Canada Basin.

\section{General observation on structure}

Although the four camp sites we visited were separated by hundreds of kilometers, they amounted to a $1,650-\mathrm{km}$ traverse across a single orogenic system that stretches from the Arctic coast in the northeast to Magadan in the southwest. The regional direction of shortening was generally northeast to southwest, but considerable local variability exists, principally due to local boundary conditions and superimposed deformation. This regional trend appears to differ from the trend of Arctic Alaska and Wrangel Island, although the significance of the divergence has yet to be understood. The style of development of the tectonic fabric and the low metamorphic grade suggest that the level of exposure of outcrops across the orogen is fairly high. The implication here is that there has not been the extreme crustal shortening and thickening that lead to gravitational collapse and unroofing of a high-grade metamorphic structure, such as the Shuswap Complex of the western Canadian Cordillera (Brown and others, 1986). The relatively slight deformation of upper Aptian and Albian sediments deposited unconformably on the folded older sediments, as well as the superposition of the linear Okhotsk-Chukotsk volcanic belt onto a basement of folded Mesozoic sediments, indicates thit deformation in the Verkhoyansk-Chukotka orogen essentially was complete by the late Aptian.

\section{Future plans}

In the summer of 1990 two Soviet scientists spent 3 weeks doin: fieldwork on northwestern Ellesmere Island, Northwest Territories. Canada, with H.P. Trettin (Geological Survey of Canada). The reciprocal to this work will be a visit by two Canadian scientists to the New Siberian Islands of the USSR in 1992. Work in these two areas will complete the essential objectives of this comparison project, and following the visit to the New Siberian Islands, a major paper will be prepared comparing geologic terranes around the Canada Basin.

\section{References}

Belyi, V.F., 1973, Okhotsk-Chukotsk fold belt and the problem of volcanic ares in northeast Asia, in Pitcher, M.G., ed., Arctic geology: American Association of Petroleum Geologists Memoir 19. p. 252-258.

_-1977, Stratigrafiya i struktury Okhotsko-Chukotskogo vulkano gennogo poyasa: Moskva, Akademiya Nauk SSSR, Dal'nevostochny Nauchnyi Tsentr, Izdatel'stvo, Nauka, 171 p. [in Russian].

Brown, R.L., Journeay, J.M., Lane, L.S., Murphy, D.C., and Rees. C.J. 1986, Obduction, backfolding and piggyback thrusting in th metamorphic hinterland of the southeastern Canadian Cordillera Journal of Structural Geology, v. 8, p. 255-268.

Cecile, M.P., and Harrison, J.C., 1986, A visit to the Soviet Arctic Episodes, v. 9. p. 240-241.

1987a, Review of the geology of Wrangel Island. USSR [abs.] Geological Association of Canada Program with Abstracts. v. 12 p. 29

- 1987b, Review of the geology of Wrangel Island, Chukchi and Eas Siberian Seas, Far Northeastern Soviet Union: Geological Survey o: Canada Open-File Report 1655, $109 \mathrm{p}$

Cecile, M.P., Harrison, J.C., Kos'ko, M.K., and Lopatin, B.G., 1988 The Canada/USSR Arctic Scientific Exchange Program-Comparisor of geological terranes around Canada Basin [abs.]: Geologica Association of Canada Program with Abstracts, v. 13, p. A18-A19.

Churkin, M., Jr., 1982, Terranes and suture zones in east-central Alaska Journal of Geophysical Research. v. 87. p. 3718-3730.

Embry, A.F., and Dixon, J., 1989, The breakup unconformity of the Amerasian Basin: Bulletin of the Geological Society of America v. 102 , p. $1526-1534$

Kos'ko, M.K., Lopatin, B.G., and Ganelin. V.G., 1990, Major geological features of the islands of the East Siberian and Chukchi Seas and the northem coast of Chukotka: Marine Geology, v. 93, p. 349-367.

Kosygin. Y.A., and Parfenov, L.M., 1981. Tectonics of the Soviet Fat East, in Nairn, A.E.M.. Churkin. M., Jr., and Stehli, F.G.. The Arctic Ocean, v. 5 of The ocean basins and margins: New York, Plenum Press, p. $377-412$

Loney, R.A., and Himnelberg, G.R., 1989. The Kanuti Ophiolite. Alaska Journal of Geophysical Research, v. 94. p. 15869-15900.

Rogozov, Yu.G., and Vasil"eva. N.M., 1968, Devonskie otlozheniya poberezh 'ya proliva Longa: Leningrad. Naucho-Issledovatel'skii Institut Geologii Arctiki, Ministerstva Geologii, SSSR, Uchyonye Zapiski. Regional'naya Geologiya, Vypusk 13, c. 151-157 [in Russian].

Rowley, D.B., and Lottes, A.L., 1988, Plate-kincmatic reconstruction of the North Atlantic and Arctic, Late Jurassic to present: Tectonophysics. v. 155, p. $73-120$.

Rozenbloom, I.S., Sosunov, G.M., and Kashina, N.S., 1987, Geological map of the Magadan Region and adjacent territories: Magadan. USSR. Ministry of Geology, northeast USSR, scale 1:2,500,000 [no series number]. 
Seslavinsky, K.B., 1979, The south Anyui geosuture, western Chukotka: Doklady Akademii Nauk SSSR, v. 249, p. 78-81.

Shilo, N.A., Akhlamova, N.N., Belyi, V.F., Bychkov, Yu.M., Goncharov, V.I., Merzlyakov, V.M., and Tsopanov, O.Kh., 1984, Guidebook for excursions on Northeast Soviet Union: International Geological Congress, 27th, Moscow, 1984, 159 p.

Shilo, N.A., Merzlyakov, V.M., Terekhov, M.I., and Til'man, S.M. 1973. The Alazeya-Oloy geosynclinal system, a new structure in the Mesozoides of the northeastern USSR: Doklady Akademii Nauk SSSR, v. 210 , p. $1174-1176$.

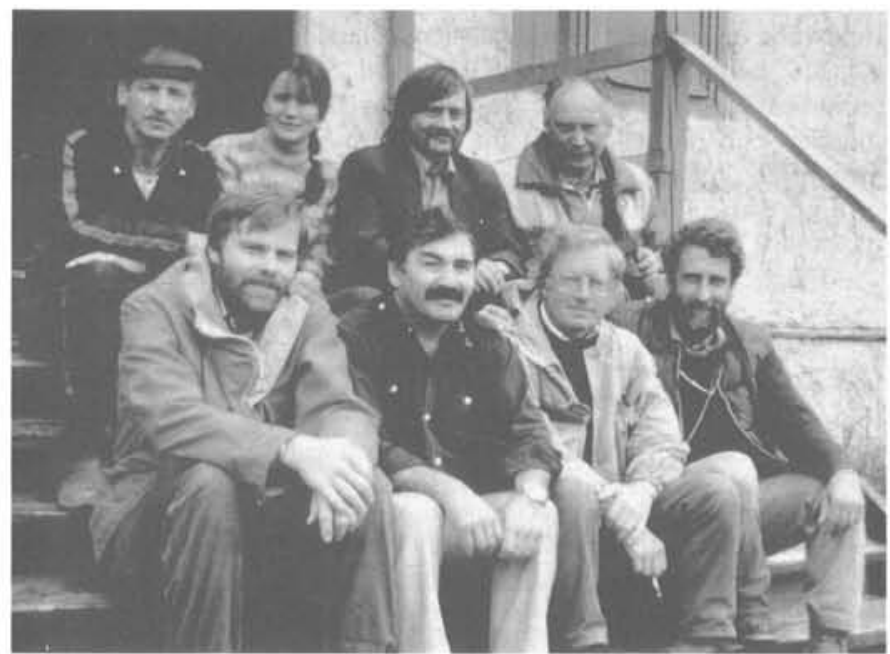

Top row from left: M.E. Gorodinsky, O.N. Vinogradova, driver Peter, and Yu.M. Bychkov. Bottom row: L.S. Lane, driver Rustan, M.K. Kos'ko, and M.P. Cecile. M.E. Gorodinsky is Chief Geologist, and Yu.M. Bychkov is a Triassic paleontologist and expert on the Mesozoic of the northeastern Soviet Union; both work with the PGO Sevostgeologia in Magadan (Interdisciplinary Scientific Research Institute, 11 Proletarskaya, Magadan 685000, USSR). They have devoted most of their careers to working in the northeastern Soviet Union. M.K. Kos'ko is a regional geologist, and O.N. Vinogradova is an upper Paleozoic paleontologist with Sevmorgeologia in Leningrad (VNIIOkeangeologia, PGO Sevmorgeologia, 120 Moika, Leningrad 190121, USSR). Both work on the Soviet arctic islands. L.S. Lane is a structural geologist, and M.P. Cecile is a regional geologist and stratigrapher. They are with the Geological Survey of Canada in Calgary (Geological Survey of Canada, 3303-33rd St., N.W., Calgary, Alberta T2L 2A7, Canada) and work in the northern Canadian Cordillera. 